IRSH 57 (20I2), Special Issue, pp. $225-252$ doi:I0.10I7/S00208590I 2000478 (C) 2012 Internationaal Instituut voor Sociale Geschiedenis

\title{
Labour Brokers in Migration: Understanding Historical and Contemporary Transnational Migration Regimes in Malaya/Malaysia
}

\author{
A M ARJIT KAUR \\ University of New England, Armidale, NSW \\ Email: akaur@une.edu.au
}

SUMMARY: Labour brokerage and its salient role in the mobility of workers across borders in Asia has been the subject of recent debate on the continuing usefulness of intermediaries in labour mobility and migration processes. Some researchers believe that labour brokerage will decline with the expansion of migrant networks, resulting in reduced transaction costs and a better deal for migrant workers. From an economic standpoint, however, reliance on brokers does not appear to have a "use-by date" in south-east Asia. Labour brokers have played an important role in organizing and facilitating officially authorized migration, particularly during the contemporary period. They undertake marketing and recruitment tasks, finance migrant workers' travel, and enable transnational labour migration to take place. Consequently, both sending and destination states have been able to concentrate on their role as regulatory "agencies", managing migration and ensuring compliance with state regulatory standards and providing labour protection. Private recruitment firms have simultaneously focused on handling the actual recruitment and placement of migrant workers. Notwithstanding this, the division of responsibilities in the migration regimes has also led to uncontrolled migration and necessitated intervention by the state during both periods. These interventions mirror the ethos of the times and are essential for understanding past and present political environments and transnational labour migration in south-east Asia.

\section{INTRODUCTION: GLOBAL-REGIONAL CONNECTIONS AND ASIAN LABOUR MIGRATIONS}

In the late nineteenth and early twentieth centuries the British Colonial Office (London) and the India Office's imperial web of connections resulted in the creation of migration corridors between Malaya, India, and China, transforming mobility in the region. Britain dominated this first wave of globalization and played a major role in Malaya and south-east Asia's greater incorporation into the new globalized system of production, trade, and investment. In most south-east Asian countries populations were sparse, and, initially, East India Company traders and administrators in 
Malaya turned to India and China for their labour needs. After Britain intervened in the Malay States in the I870s, the British created a demand for migrant workers and also developed "manpower supply chains" connecting India, China, and Malaya. Colonial Malaya's economy subsequently became part of the Old International Division of Labour, producing commodities for industrializing Britain and other northern hemisphere countries. This migration phase marked a new chapter in international labour migration in south-east Asia.

The Malayan government also became the official state agency for organizing Indian labour recruitment after the i870s and developed a migration infrastructure to expand labour mobility and ensure compliance with Indian legislation. This task involved managing emigration procedures at ports, legislating on shipboard conditions, ensuring that migrants emigrated "willingly", and also that they met minimum health standards. Furthermore, the government generated migration by improving transport infrastructures, subsidizing travel, initiating liberal migration regulations, and establishing indentured labour regimes. Concurrently, Chinese merchants who had a long history of trade connections in southeast Asia also facilitated and encouraged Chinese immigration to Malaya. Most of them had obtained mineral or agricultural concessions from local rulers in frontier zones prior to British hegemony in Malaya. Their contacts and familiarity with conditions in Malaya enabled them to conduct their business without relying on the British. Thus, unlike Indian labour recruitment and employment, the Malayan establishment did not play a key role in either the recruitment or employment of Chinese labour migrants.

By the late I930s and I940s, wars and globally depressed trade conditions resulted in reduced transnational movements to Malaya, following the Malayan government's implementation of border control systems and legislation to restrict immigration. Then, after World War II and subsequent decolonization measures, universal travel documents became standardized and the independent Malayan nation state introduced stringent regulations to control cross-border movements. During this phase, the United States emerged as the dominant economic power in a second wave of globalization characterized by the further integration of economic activities and labour markets. Additionally, since the I970s and I980s, and following Singapore's separation from Malaysia in 1965 , a cheap labour supply in the context of the New International Division of Labour became an integral factor in attracting foreign investment and enabling economic growth. Immigration was again seen by both Malaysia and Singapore as a viable solution to increase their labour supply against the backdrop of demographic decline and an ageing workforce.

Labour mobility in south-east Asia/Malaysia is presently recognizable by its predominantly intra- and sub-regional features, but also by wider 
Asian movements, thus indicating a new chapter in transnational labour movements. Regional cooperation in the economic arena has further promoted both regionalized as well as global labour mobility, encompassing a greater number of source countries. Migration has thus expanded exponentially and includes both highly skilled and low-skilled labour movements. The state unilaterally regulates migration through specific governance measures which include state legislation and policies on foreign labour employment; a constructed legality of movement through documents such as passports and work visas; and labour agreements. Most importantly, labour brokerage has expanded considerably in both destination and sending states and comprises both large and small private labour agencies that operate at the hub of new transnational labour migration regimes.

This article examines comparatively the role of the state and labour brokers in migration regimes in Malaya/Malaysia in historical and contemporary perspectives. It also assesses the connections between the state and labour brokers in the migration infrastructure. Finally, it considers why a detailed knowledge of the specific recruitment practices of labour brokers is necessary to understand the rise in contemporary labour mobility in the region.

\section{The British Empire and labour migration in south-east Asia, 1870s-1930s}

From about the late nineteenth century the growth of the international economy and associated demand for Asian commodities for the world market corresponded with the region's greater integration into the new globalized system of production, trade, and investment. The political map of south-east Asia was redrawn by the European colonizers and the ensuing new geographical and administrative frameworks comprised six major countries - British Burma, British Malaya, French Indo-China, Dutch Indonesia, the Spanish (later American) Philippines, and independent Thailand. British imperialism and the spread of capitalism in Asia also linked China and India more directly with south-east Asia. The new economic corridors, extending from southern China and southern India to south-east Asia, facilitated labour market integration, resulting in mass proletarian migration to south-east Asia. These economic corridors also helped create a demand for migrant workers in the colonies. The British thus transformed mobility in the region through their open border policy and officially authorized opportunities for Chinese and Indian labour migration.

Prior to these developments, the British East India Company had established settlements in Malaya and Sumatra for plantation agriculture and imported Indian slave and convict labour to cultivate the crops. After British slave emancipation in I 834 , and especially the provisions of the Indian Penal Code of I860, the slave trade and slavery in India and 
Malaya ended. ${ }^{\mathrm{I}}$ It was thus essential to secure new labour sources for the economic development of British Malaya, which comprised three political units: the East India Company's existing Straits Settlements ports Singapore, Penang, and Malacca (now colonies); the Federated Malay States (FMS); and the Unfederated Malay States (UMS).

The Malay states were effectively governed as colonies, though they were regarded as protectorates, and remained nominally under their own rulers. Singapore was transformed into the leading port city in the region and became the main commercial and financial centre, and administrative capital, of British Malaya. Globalization and the complex exchanges and interconnections with industrial processes in Europe and elsewhere and commodities of empire were accordingly decisive issues in promoting labour mobility and the building up of a viable "freer" labour supply in the region. Simultaneously, the increased taxes on peasants and new land regulations in India had impoverished the peasantry and were a driver of labour migration.

These factors foreshadowed the coordination and regulation of migration in the form of voluntary indentured labour contracts and the organization of travel arrangements. The growth of this new form of labour engagement is usually considered as marking the start of the modern system of wage contract labour in south-east Asia. ${ }^{2}$ The new sources of labour supply corresponded with earlier migrant flows. As noted previously, Chinese enterprises had drawn on workers from China, and this pattern continued. Similarly, European employers had a preference for Indian labour based on their experiences with them in the Straits Settlements and elsewhere. Indian and Chinese mass migration was thus interwoven with imperialism, social transformation, and the new economic organizations of plantations, mines, and markets.

From the outset, labour intermediaries played an integral role in Asian migration. Labour brokers (or employers as intermediaries) paid the migrants' passage and travel costs and the migrants had to work for a set period until they had cleared their debts. Indian migrants moved largely between two colonial establishments - India and Malaya - under the overall jurisdiction of the Colonial Office in London. Hence the "British establishment" played an important role in policing migration processes and regulated employment and labour conditions in consultation with employers. Chinese migrants, who have variously been described as "selfdriven", "self-organized", and "speculative", went to a wide range of countries. Their migration overseas could best be described as being

I. I.M. Cumpston, Indians Overseas in British Territories, I834-I854 (London, 1953), p. 85.

2. Amarjit Kaur, Wage Labour in Southeast Asia since I840: Globalisation, the International Division of Labour, and Labour Transformations (Basingstoke, 2004), chs 3-4. 
organized by intermediaries under both a personal recruitment system and a mixture of recruitment arrangements, and largely directed by Chinese business interests. There was no recognized "establishment body", and the influence of secret societies was ubiquitous.

According to Huff and Caggiano, the immigration rate (immigrants per I,000 population) for Malaya (Peninsula Malaysia and Singapore) was the highest in the world throughout the period I88I-1939. They have also estimated that between I9I I and 1929 Chinese and Indian gross migration to Burma, Malaya, and Thailand was twice as high as gross migration to the United States. ${ }^{4}$ While European migrations were voluntary and largely free, Chinese and Indian labour migration took place under free and semifree arrangements, some of which, though technically legal, had elements of illegality. Additionally, labour brokers played a pivotal role in migration.

The following account of Indian and Chinese recruitment and employment in the rubber and tin industries respectively broadens the scope of the role of the state and labour brokers in Malaya and underlines the contrasts between the migration experiences of the two groups.

\section{IMPERIAL HEGEMONIES AND LABOUR INTERMEDIARIES}

After the collapse of the East India Company in I 858, the Straits Settlements were placed under the direct control of the British government and constitutionally separated from India in I 867. This action was followed by a ban on Indian labour migration to the Straits Settlements. The ban was then lifted in 1872 at the request of European planters, on condition that the Straits Settlements colonial government take over the regulation of Indian labour emigration to Malaya. Henceforth, emigration to the Straits Settlements was permitted under a modified version of the Indian Act XIII of I864. The Magistrate at Nagapattinam (the main embarkation port in southern India) was appointed Protector of Indian Labour to ensure that professional recruiters did not engage in speculative recruitment and misrepresent employment and working conditions overseas. The professional recruiters included private labour brokers in the Straits Settlements and India and ship owners and merchants who had previously recruited Indians for the East India Company and European sugar planters.

Other conditions included the screening of prospective emigrants by medical emigration agents and an evaluation of migrants' motivations and

3. Gregg Huff and Giovanni Caggiano, "Globalization and Labor Market Integration in Late Nineteenth and Early Twentieth-Century Asia", Research in Economic History, 25 (2008), pp. 255-317.

4. Idem, "Globalization, Immigration, and Lewisian Elastic Labor in Pre-World War II Southeast Asia”, Journal of Economic History, 67 (2007), pp. 33-68, Table I. 
their ability to work in Malaya. Indian migrants were allowed to travel only as free individuals, and Indian nationalists and social reformers entered the debate about this, thus adding a "new set of imperatives and agendas" to the conversation. ${ }^{5}$ Subsequently, the Straits Settlements government compiled its own labour code in I 876 , to regulate indentured labour migration to Malaya. ${ }^{6}$ The code laid down the labour contract's salient terms and the labour conditions for Indian emigrants. Henceforth, Indian labour recruits arriving at Penang (the port of disembarkation in Malaya) arrived with a debt obligation of Straits \$ $_{17}$ to cover their passage costs and an advance on their pay, which was recoverable from their wages. ${ }^{7}$ The Malayan coffee planters meanwhile developed an alternative recruitment method, the kangani method, to recruit Indian labour (see below).

This code was also considered restrictive, and the Straits Settlements administration subsequently requested that it be revoked. The Indian government then rescinded the legislation in I $88 \mathrm{I}$, effectively removing restrictions on Indian emigration to Malaya. In I 884 new legislation, the Indian Immigration Ordinance, was approved in the Straits Settlements to replace the previous legislation. Thus, the Indian indentured labourer was no longer obliged to sign a contract until his arrival in the Straits Settlements. Moreover, in I 887 the Straits Settlements and several Malay States governments agreed to provide a steamship subsidy to transport Indian labour emigrants to Malaya. The Indian government was also progressively persuaded to instigate new measures to encourage emigration to Malaya, to revise recruitment regulations to end the monopoly of the Indian recruiting agents, and to facilitate emigration by establishing labour depots for receiving and processing Indian emigrants in southern India. ${ }^{8}$

In I 897 all restrictions on Indian emigration to Malaya were abolished and the India Office's jurisdiction over Indian emigration to Malaya ended. Britain's larger political agenda for both India and Malaya was thus secured. More importantly, Malaya's future economic growth, with a continuous supply of Indian labour for plantations, railway, road construction, and other public projects, was guaranteed. Politically too, the British extended their hold over Malaya and contributed to the spread of Western enterprise there. Between I874 and 1914, Britain brought the

5. R.N. Jackson, Immigrant Labour and the Development of Malaya, 1786-1920 (Kuala Lumpur, 1961), p. 163; Sunil Amrith, "Indians Overseas? Governing Tamil Migration to Malaya, I870-194I", Past and Present, 208 (2010), pp. 239-24I.

6. Straits Settlements Ordinance No. I, also known as the Indian Immigrants Protection Ordinance of 1876 , or the Indian Act No. 5 of 1877.

7. Hugh Tinker, A New System of Slavery: The Export of Indian Labour Overseas, 1830-1920 (London, I974), p. I2.

8. Jackson, Immigrant Labour and the Development of Malaya, pp. 62-69; Virginia Thompson, Labor Problems in Southeast Asia (New Haven, CT, 1947), pp. 62-65. 


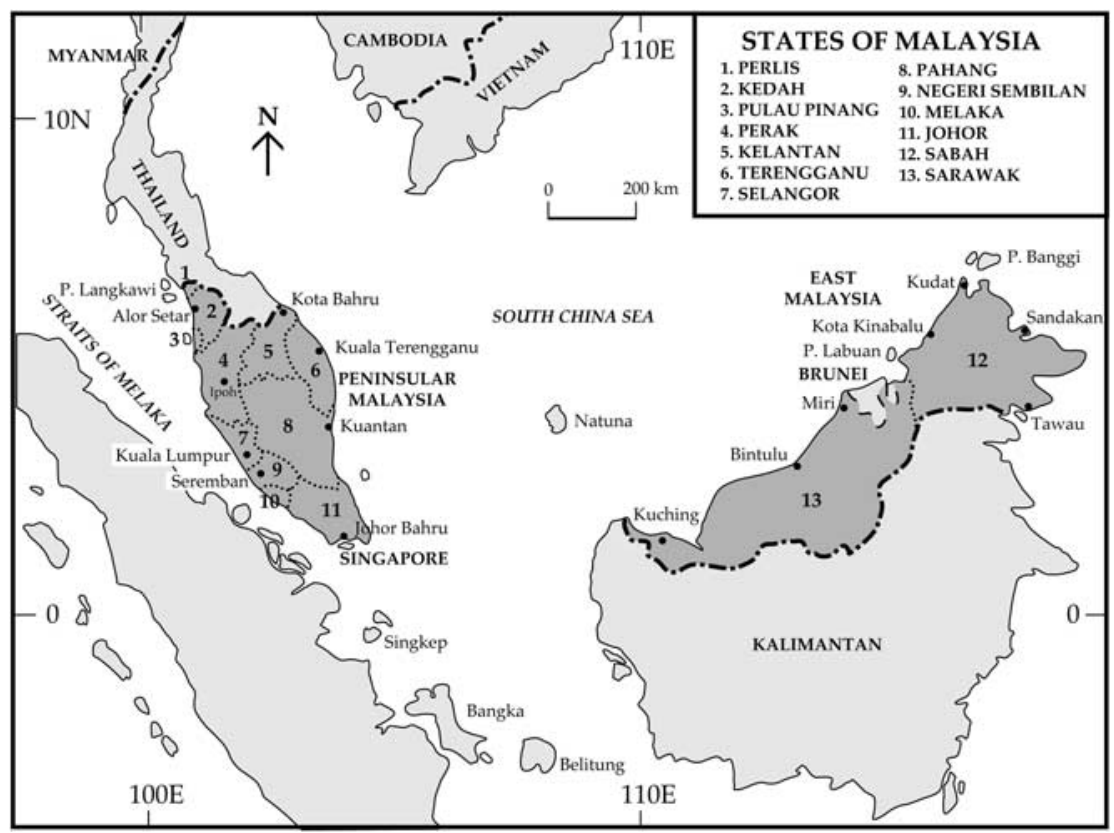

Figure I. Map of Malaysia.

Malay States (the FMS and the UMS) under formal protectorate status (see Figure I).

The moving frontier in Malaya both supported and advanced the development of a "permanent" wage labour force in the country in connection with the expansion of the tin and rubber industries. The state also helped transform the cost structure and capacity of the rubber industry by privileging plantation production and Western (mainly British) investors. Afterwards, Western capital dominated too in the tin sector. The state also established modern bureaucratic structures, introduced new administrative and legal frameworks, and built a unified transport system in the country. ${ }^{9}$ By 1910, rubber covered approximately 225,000 hectares, rising to 891,000 hectares in 1921. This accounted for 53 per cent of the total land under rubber in south and south-east Asia; and Malayan rubber exports also rose from 6,500 to 204,000 tonnes between 1910 and 1919. ${ }^{\circ}$ The remarkable expansion of the rubber and tin industries was due largely to an unlimited supply of mainly Indian and Chinese migrant labour.

9. Amarjit Kaur, Bridge and Barrier: Transport and Communications in Colonial Malaya, I870-I957 (Singapore, I985).

I0. John Drabble, An Economic History of Malaysia, c.I800-I990 (London, 2000), pp. 53-54. 
The colonial state as regulatory agency, labour broker, and employer: The case of Indian migrant workers

The principal Indian labour migrations were to Malaya, Burma, and Thailand, while the port cities of Singapore and Penang functioned as important transit hubs. The state and planters (as employers) essentially regarded Indian labourers headed for Malaya as another tradable commodity in the production cycle. All the necessary arrangements for their sojourn abroad - recruitment, transportation, and employment - were made by four parties: the sub-imperial Indian government (or India Office); the Colonial Office in London; the Malayan (Straits Settlements and FMS) government; and Western entrepreneurs. Indian labour migrants comprised low-caste men, mainly from the Tanjore, Trichinopoly, and North Arcot districts in southern India. These districts were particularly vulnerable to drought, and famine and landlessness was widespread. ${ }^{\text {II }}$

Since most Indian emigrants lacked the funds for spontaneous mass migration, the sub-imperial India Office regulated Indian labour recruitment for Malaya for the benefit of the Malayan administration. In Malaya, governance structures for the plantation labour regime and public projects rested on two pillars - the mobilization of a largely migrant labour force that facilitated the use of economic and extra-economic measures to maintain low wage bills; and an ethnic (and gender) differentiation of the labour force that enabled the manipulation of both workers and wages.

Private labour brokers/intermediaries were "entrusted" with the important task of facilitating and driving labour migration under the auspices of two recruitment methods - the indenture system and its variant, the kangani system. The indenture recruitment method authorized employers to utilize enforceable, written labour contracts. Prior to the abolition of indenture, Malayan planters either engaged the services of one of the labour recruitment firms in Nagapattinam or Madras, or sent their own agents to southern India to recruit labourers directly. The agents advanced money to individuals wanting to migrate to Malaya, the advance being conditional on the intending migrants signing a contract on arrival in the country. The migrants were then considered to be under indenture to their employers for a fixed period, varying from three to five years. (The indenture period was reduced to three years after the 1904 Labour Ordinance took effect.) ${ }^{\mathrm{I} 2}$ Once the workers' indenture period had been completed, they were given the option of re-indenture for a further period or released from indenture, providing they had settled their recruitment and other passage costs. 
Employers were responsible for all recruitment charges and expenses involved in transporting workers to Malaya. Wages were fixed at the time of recruitment and were not negotiable. Indian workers' wages were calculated after deducting this outlay from their wages. ${ }^{{ }^{3} 3}$ Most planters regarded this migration method as an essential tool for labour retention and circulation to maintain a stable workforce on rubber plantations. The low wages meant that workers were forced to extend their contracts and re-indenture themselves. Crucially, workers were "bound" to employers during their period of indenture and were treated as unfree men. Employers further used sanctions to enforce labour contracts, and breaches of these contracts were regarded as criminal, not civil offences.

Subsequently, rubber planters started utilizing their own "trusted" workers as labour brokers to recruit Indian labour, thus introducing a chain-migration outcome based on specific recruitment areas in southern India. This system, known as the kangani recruitment system, was primarily a personal or informal recruitment system and it became the preferred recruitment method after 1910. The word kangani means "overseer" or "foreman" in Tamil, and the kangani, typically a labourer already employed on the plantation, was delegated by his employer to recruit workers from his village. This system was preferred by most planters due to the lower costs incurred in using the kangani's services compared with the higher costs incurred under the indenture method, which involved payment of fees to recruitment agencies. Indian labour intermediaries were also often blamed for restrictions in labour supply. Crucially, the kangani provided the vital connection between poverty stricken rural southern India and the frontier regions of Malaya, and enabled Indian migration to take place. Planters preferred this method given that the prospect of workers absconding became less likely, especially since the kangani had a vested interest in ensuring that the labourers did not abscond.

The kangani method utilized social capital or migration networks to assist workers' transition to plantation life in Malaya. These networks were essentially sending networks that articulated with the particular receiving plantation networks in Malaya. The kangani was not only a powerful intermediary, he also received "head money" for each day worked by the workers, and stood to forfeit that if workers absconded. ${ }^{I 4}$ The kangani also related to the labourers in his roles as plantation storeowner and moneylender, and workers frequently became indebted to him. Arudsothy argues that the kangani system was a "variant of the indenture system, as in effect, the debt-bondage relationship between

I3. C. Kondapi, Indians Overseas, I838-1949 (New Delhi, I95 I), pp. 8-29.

I4. Sandhu, Indians in Malaya, p. гог. 
servant and master still remained, although indirectly". ${ }^{\text {s }}$ Nevertheless, although planters delegated the actual recruitment task to the kangani, it is important to bear in mind that employers were the "true" labour intermediaries in Indian labour recruitment to Malaya, and were unhampered by any Indian legislation. The Malayan government, however, considered the kangani method a major improvement on the indenture system because, theoretically, labourers were no longer required to have written contracts, were "free" workers, and had greater personal (as opposed to "occupational") mobility.

On the plantation the new migrants lived in compound accommodation and their social life revolved around plantation activities and society. Nevertheless, the isolation of plantations, timidity of the workers, and the plantation boundary reduced this mobility. Furthermore, the labour force comprised mainly male workers. Married men were discouraged from emigrating because, since wages were low, they could not afford to bring their families; the payment norm was a single-person wage; working conditions were harsh; and accommodation was available for single men only. In its I 864 legislation (Act XIII), the Indian government had stipulated that female recruits had to be included in all labour shipments overseas in the following proportion: 25 women to 100 men. ${ }^{16}$ However, Malaya was repeatedly exempted from this gender-ratio stipulation due to a dualism in recruitment/regulation procedures governing Indian labour in Malaya. As noted earlier, the India Office had lost its jurisdiction over Indian emigration to Malaya in 1897 , consistent with Britain's emphasis on the wider British Empire interests.

The Malayan government's expanding labour requirements for public works development, the growing competition for labour, and an upsurge in labour "poaching" activity signalled a change in the state's role as both a regulatory agency and a labour broker. In 1907 the Malayan government established a centralized quasi-official body, the Indian Immigration Committee (IIC), to facilitate and regulate southern Indian labour recruitment for Malaya. This move foreshadowed two key changes in the Indian migration regime. First, the Malayan state officially became the "sole" labour broker and had jurisdiction over all Indian labour recruitment for Malaya. It may even be considered to have been a "labour-brokerage" state for Indian labour recruitment. Second, the state then gave itself greater regulatory powers in the Indian migration regime.

In 1908 too a Tamil Immigration Fund (later Indian Immigration Fund) was established to recruit Indian labour directly for the government and

I 5. P. Arudsothy, “The Labour Force in a Dual Economy” (Ph.D., Glasgow University, I986), p. 75 .

I6. Major G. St John Orde-Browne, Labour Conditions in Ceylon, Mauritius and Malaya (Cmd. 6423) (London, 1943). 
to meet the plantation sector's needs, and to provide free passage for labourers destined for Malaya. All employers of Indian labour were required to pay a quarterly levy or tax to the fund to cover the travel and related costs of Indian migrants to Malaya. This meant that Indian labour, once recruited under the auspices of the fund, was subsequently either confined to plantations or state development projects in emerging townships. In return, Indian workers headed for Malaya were no longer required to pay their travel costs and were free of debt obligations. The actual recruitment was entrusted to kanganis. The Malayan administration introduced new legislation as the system developed, including the licensing of kanganis to minimize potential abuse of migrants and the stipulation that migrants be employed on a monthly basis only.

These developments also encouraged voluntary migration, and prospective migrants went to the Indian depots for assisted migration to Malaya. Additionally, the indenture recruitment method was phased out in I9IO, with the last contracts ending in I9I3. For planters this centralized recruitment system cost less than the "old" kangani method since other intermediaries were circumvented, and the kangani's power over workers gradually declined. Nevertheless, although workers arrived in Malaya without any debt obligations, they continued to be considered under contract to plantation owners and under the supervision of the kangani. Until 1923, the state also upheld penal sanctions for breaches of labour contracts under the new regulations. Kangani-assisted recruitment gradually declined in the late I920s, was suspended during the Great Depression, and was formally abolished in 1938. In the I930s government assistance in labour recruitment was regarded as inappropriate and the Tamil Immigration Fund was utilized to repatriate unemployed workers. After the Great Depression there was less pressure from planters for a centrally managed labour recruitment system since government-assisted migration was well publicized and most repatriated workers could finance their own return trips.

Thousands of Indian migrants arrived annually in Malaya under the two recruitment systems. Between I 844 and I910, about 250,000 indentured labourers came to Malaya. ${ }^{17}$ The peak of kangani-assisted recruitment occurred in the I9I0s, when about 50,000 to 80,000 Indian workers per annum arrived. During the period I $844-1938$, kangani-assisted migration accounted for 62.2 per cent of total Indian labour migration, compared with $\mathrm{I} 3$ per cent of indentured labour migration. Moreover, whereas in 1920 only I 2 per cent of Indian workers had not been recruited, this proportion had increased to over 9I per cent by the 1930s. ${ }^{18}$ In the first

17. Sandhu, Indians in Malaya, p. 81; Sinnappah Arasaratnam, Indians in Malaysia and Singapore (Kuala Lumpur, 1979, rev. edn).

I8. Virginia Thompson, Postmortem on Malaya (New York, I943), p. I23. 


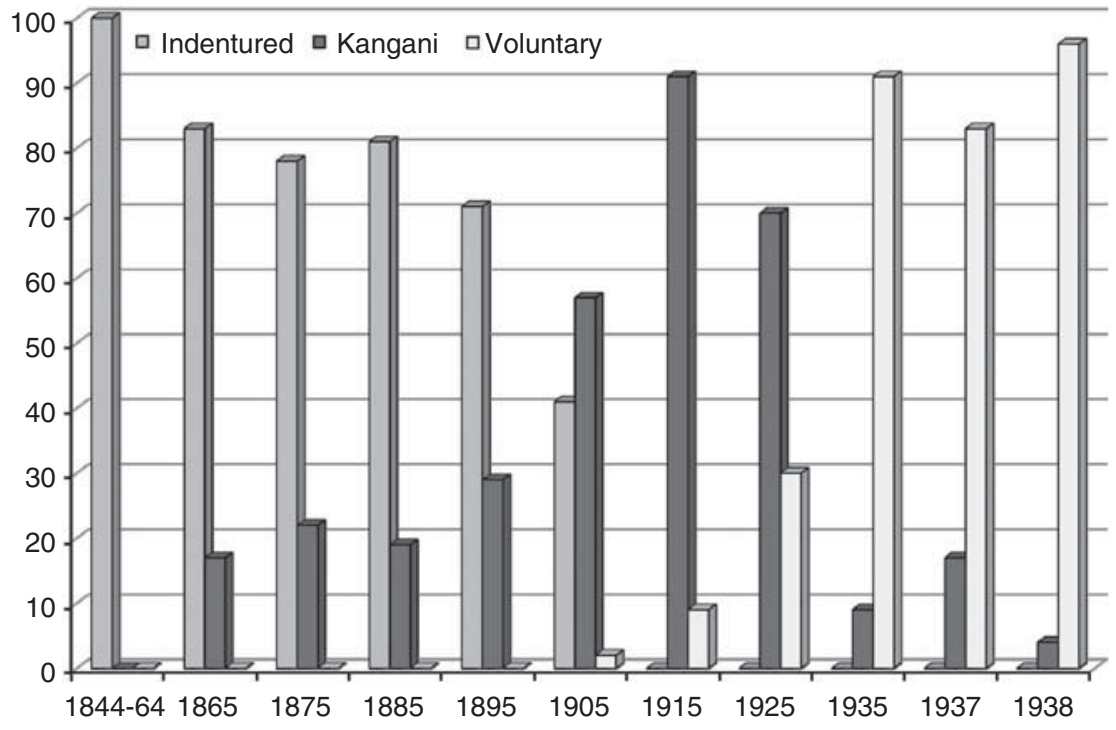

Figure 2. Indian labour recruitment by recruitment method, 1844-1938 (percentage). Adapted from Sandhu, Indians in Malaya, Appendix 2, pp. 306-309.

four decades of the twentieth century, Indians accounted for between 70 to 80 per cent of the FMS plantation labour force. ${ }^{19}$

The shift in recruitment patterns and breakdown of Indian migrant workers by recruitment system is shown in Figure 2. Most Indian migrants were single men and were taken to frontier plantations won from the jungle. The Indian sex ratio improved under the kangani method of recruitment. As plantation work became differentiated and specialized as well, with differing pay scales for tapping, weeding, and factory tasks, women's migration was encouraged and assisted through the kangani system. The kangani also earned a higher commission for women workers as well as for married couples. Female immigration was also intended to facilitate the reproduction of workers and facilitate the settlement of Indians on plantations.

Two events subsequently impacted on the state's premier regulatory and intermediary roles. First, by the early i920s Indian nationalists and social reformers had become more vocal in their demands for better protection for Indian workers overseas and the issue of continuing emigration of Indians. Indians comprised about 75 per cent of the estate 
(plantation) labour force, a figure that had remained fairly constant since 1907. Hence in 1922, when the Indian Emigration Act was scheduled to be implemented in India, the question arose as to whether Indian emigration to Malaya should continue after March 1923 (when Malaya truly came under the act's provisions). Since the demand for Indian labour was still huge, the Malayan government implemented five major reforms that had broad implications for Indian welfare and the Indian sex ratio in Malaya.

First, the state adopted the principle of a standard wage, as opposed to a minimum wage. Second, an "improved" sex ratio on the plantations, in line with earlier emigration acts, was also endorsed. Rule 23 of the Indian Emigration Act (Act VII of 1922) specified that there should be at least one female emigrant for every I.5 males assisted to immigrate as labourers to Malaya. Third, all penal provisions relating to Indian workers were abolished in the Malayan Labour Codes of I92 I and I923. ${ }^{\circ}$ Fourth, the state commissioned a report on Indian workers' health on plantations to investigate the high mortality rates there and recommended the provision of improved healthcare facilities. ${ }^{21}$ This led to "better" facilities on plantations. Fifth, an agent of the Indian government was appointed by India to report on health and general labour conditions on the estates. Although he and successive agents had little authority in Malaya, the appointment represented a small step in the Indian government's attempts to ensure compliance with Indian regulations on workers' welfare.

Generally, by the i93os the labour-brokerage-cum-regulatory role of the state for Indian labour had undergone some transformations. The impetus for these reforms came from external forces - from India and Indian nationalists. This development mirrors the important role of NGOs in present-day Malaysia in undertaking associational activity for and on behalf of foreign labour in the country.

\section{Chinese mining labour and labour brokers}

Chinese merchants had a long history of trade connections in south-east Asia and obtained mineral or agricultural concessions from local rulers in frontier zones prior to the establishment of British rule in Malaya. Their contacts and familiarity with conditions in Malaya enabled them to conduct their business largely without the intervention and assistance of the British. Thus, unlike the case of Indian labour recruitment and

20. Orde-Browne, Labour Conditions in Ceylon, Mauritius and Malaya.

21. Report of the Commission Appointed to Enquire into Certain Matters Affecting the Health of Estates in the Federated Malay States 1924, 2 vols (Singapore, 1924), cited in Amarjit Kaur, "Indian Labour, Labour Standards, and Workers' Health in Burma and Malaya, 1900-1940", Modern Asian Studies, 40 (2006), pp. 425-475. 


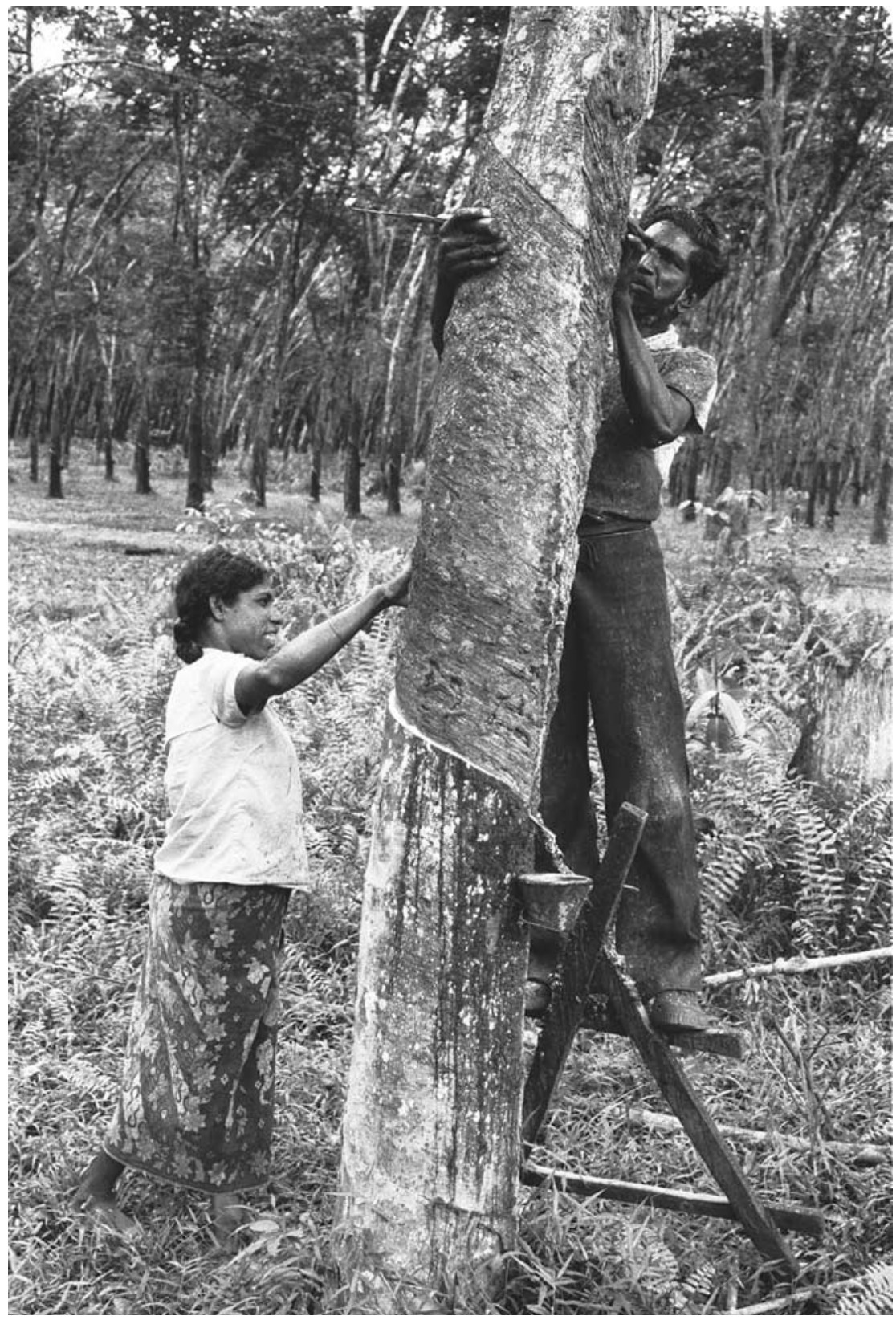

Figure 3. Indian rubber tappers in a rubber plantation in Pahang (Malaysia), 1978. Photograph: Ian Metcalfe. 
employment, the Malayan establishment did not play a key role in either the recruitment or employment of Chinese labour migrants. However, private labour brokers played a major role in Chinese labour migration.

The development of large-scale tin mining in Malaya in the second half of the nineteenth century was due mainly to the existence of merchant capital in the Straits Settlements and the enterprise of certain Malay chiefs who invited the Chinese merchants to develop tin mining in their territories. These Straits Chinese merchants initially obtained Chinese labour from the Straits Settlements. When demand outstripped supply, the merchants turned to southern China to recruit new migrants to work in the mines. The Chinese originated mostly from the coastal districts of Fujian Province, the Chaozhou-speaking districts in north-eastern Guangdong Province, and the Pearl River Delta counties in southern Guangdong. Their journeys took place through Chinese ports that had been annexed as colonies, for example Hong Kong and Macau, and the Chinese treaty ports opened to British and other Western traders following China's defeat in the Anglo-Chinese trade conflicts known as the First and Second Opium Wars. The Chinese government did not support Chinese emigration until the late nineteenth century, making it difficult to utilize open, regulated recruitment arrangements.

The Chinese migration method included a "kinship-based" migration network in China and the credit-ticket network in the destination country, both of which involved labour brokers. The kinship-based migration network involved recruiter-couriers, who recruited migrants from their own villages and regions, and relatives or friends from the migrants' home town normally guaranteed the passage costs and travel expenses. The credit-ticket system, which the bulk of migrants relied upon, necessitated the passage costs and travel expenses being paid by labour brokers, captains of junks, or labour agencies. The crux of their labour contract revolved around the question of how, when, and to whom the passage costs would be repaid. The system exemplified the coolie trade that supplied the bulk of Chinese labour migrants. This trade was controlled by both Chinese and foreign agencies, including British, American, and Dutch firms in the Chinese treaty ports. Prior to I876, there were at least six coolie agencies operating in the treaty ports that supplied coolies bound for Singapore. Three of these were Chineseowned, two of which were based at Swatow in Guangdong Province, while the third was based in Amoy in Fujian Province. Two of these also had branch offices in Singapore for receiving coolies. ${ }^{22}$

22. Yen Ching-Hwang, A Social History of the Chinese in Singapore and Malaya, I800-19II (Singapore, 1986), p. 7; Carl Trocki, Opium and Empire: Chinese Society in Colonial Singapore I800-I9I0 (Ithaca, NY, I990), p. I I. 
The labourers were held at receiving depots in Singapore upon arrival at their destination, until their potential employers had paid the passage costs owed by them to either the labour brokers, junk captains, or labour agencies. The immigrants then normally entered into verbal or written contracts for the repayment of their debts in the form of labour service. If no employer came forward to hire the labourer, they were often "sold off" to other employers in adjoining territories. Moreover, there were no conventions for regulating the migrants' subsequent destiny or determining their working conditions. The influence of Chinese secret societies was pervasive and migrants continued to be controlled by secret society members, who prevented them from escaping. When the labourers had repaid their debt (with interest), they were released from their obligations and free to choose their next employer and place of employment. ${ }^{23}$

Tin mining was organized under the auspices of the Chinese kongsi, which was a Chinese business cooperative that integrated the maintenance of social control and solidarity. ${ }^{24}$ The kongsi also functioned as a resilient organization in a frontier society, based on bonds of brotherhood and partnership in economic activity. The isolation of the tin mines from colonial towns, Malay settlement areas, or ports meant that the kongsi had to provide a multiplicity of ancillary services required by workers and an institutional framework into which new arrivals, the workers, were inducted. The kongsi thus offered a sense of security and identity - it relied on a variety of mechanisms, including a personal recruitment system, kinship links, and clan ties and provincial connections. Membership of secret societies was often obligatory - the society offered protection and established its own law and code of conduct. ${ }^{25}$ The labourintensive nature of the tin industry ensured the continuing dominance of labour brokers in the industry in the second decade of the twentieth century. ${ }^{26}$

The British viewed the credit-ticket system with suspicion owing to reports of abuse of labourers, and gradually took measures to free up the Chinese labour market. This variant of indentured servitude gradually came under government scrutiny, and in I877 the Straits Settlements administration established Chinese protectorates to regulate Chinese labour recruitment, license the recruiting agents, and register labour contracts. However, the recruitment system did not show much improvement, despite a treaty between China and Britain in 1904. This treaty also permitted the British to recruit any number of Chinese workers at a set fee. But there were no clauses protecting these workers. ${ }^{27}$ Nevertheless, by the I 890 s secret societies had also been banned and the degree of control exerted over

23. Yen, Social History of the Chinese in Singapore and Malaya; Trocki, Opium and Empire.

24. Ibid., p. I.

25. Yen, Social History of the Chinese in Singapore and Malaya, pp. I I7-1 I8.

26. Kaur, Wage Labour in Southeast Asia since 1840, ch. 3.

27. Li Dun Jen, British Malaya: An Economic Analysis (Kuala Lumpur, 1982), pp. I37-I40. 


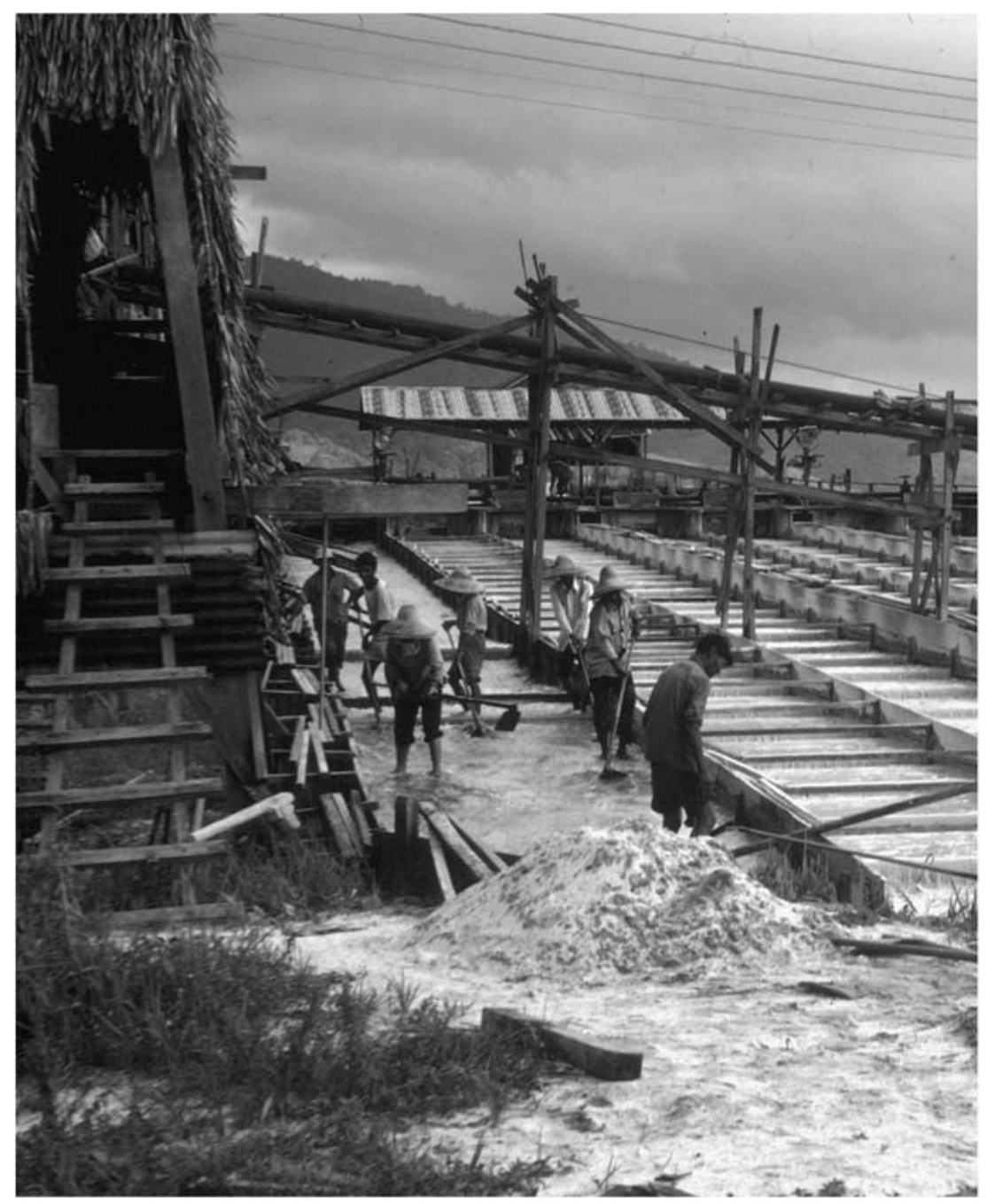

Figure 4. Chinese miners working on a palong at a Chinese gravel pump tin mine in the Kinta Valley (Malaysia), I978.

Photograph: Ian Metcalfe.

workers by mine owners reduced. The power of the Kapitan China (the Chinese community head) also weakened, and the position was abolished in 1902. Furthermore, following the abolition of the indenture contract system for Indian labour in I9I0 the system was also officially abolished for Chinese labour recruitment in I9I4.

Chinese migrants were more advantaged compared to Indian migrants because of their long-standing links and social capital in the Straits 
Settlements; their migration method was more speculative; and they were bound only by their financial obligations - once these had been settled they were free to move elsewhere. Given that the larger mining areas in the Malay Peninsula evolved into colonial townships with associated facilities, these emerging towns opened new opportunities for them. By I93 I most Chinese immigrants were employed as traders and shopkeepers rather than in mining and agriculture. ${ }^{28}$ The characteristics of the tin supply were a contributory factor. Since tin is a non-renewable asset, workers moved on to other ventures once a mine had been worked. Moreover, as the mining industry was progressively mechanized in the I920s, control of the industry also shifted to Western entrepreneurs, thus contributing to the growth of a freer Chinese labour force in this industry.

The Kapitan China also manoeuvred between the British administrators, Malay rulers, and Chinese communities. Some Chinese went into urban occupations or became smallholders; others worked as contract plantation workers under "contractor intermediaries" who hired out their services to planters. ${ }^{29}$ As a temporary contract workforce they were not subject to the paternalistic structures of plantations or of their Western/Asian owners, but remained under the authority of their own contractors and also earned higher wages. These contractors were responsible for the workers' accommodation and other facilities and often moved them around in search of better-paying opportunities. Personal profit, not ethnicity or solidarity, typified their employment status in Malaya and assisted them in advancing their personal economic interests. Consequently, the Chinese miners' migration method gave them additional occupational and personal mobility entwined with a greater sense of freedom, and the nature of their employment and urban settlement enabled them to make the transition to a freer workforce sooner than Indian migrant workers.

The Indian migration method came under the purview of British India and ultimately Britain, and the Malayan establishment was both the regulatory agency and labour broker. All three parties enforced labour control and subjugation in the context of a settled labour force. They thus immobilized the mobile Indian migrant in Malaya whether in "private" plantation work or "official" public works projects and housing. Indians also took a much longer period to repay their travel and passage obligations. The paternalistic policies further ensured that Indians remained powerless, and since the plantation was the boundary of their existence they were denied access to English education in the townships as well as better medical services and contact with other communities.

28. T.E. Smith, "Immigration and Permanent Settlement of Chinese and Indians in Malaya, and the Future Growth of the Malay and Chinese Communities", in C.D. Cowan (ed.), The Economic Development of South-East Asia (London, 1964), p. 176.

29. Kaur, Wage Labour in Southeast Asia since I840, ch. 3. 
Table I. Malayan population by racial group, I9II-I947 (in ooos, percentages as a proportion of total population).

\begin{tabular}{|c|c|c|c|c|c|c|}
\hline \multirow[b]{2}{*}{ Year } & \multicolumn{2}{|c|}{ Malaysians* } & \multicolumn{2}{|c|}{ Chinese } & \multicolumn{2}{|c|}{ Indians } \\
\hline & No & $\%$ & No & $\%$ & No & $\%$ \\
\hline 1911 & 1,438 & 54 & 917 & 34 & 267 & 10 \\
\hline 1921 & 1,651 & 49 & 1,175 & 35 & 472 & 14 \\
\hline 1931 & 1,962 & 45 & 1,709 & 39 & 624 & 14 \\
\hline 1947 & 2,544 & 43 & 2,615 & 45 & 600 & 10 \\
\hline
\end{tabular}

* "Malaysians" include Malays and Indonesians. The table excludes "other" races. Source: Malaya: Census Reports I9I I-I947.

\section{Border controls and immigrant labour}

As outlined above, the Malayan Administration had adopted an open immigration policy that led to permanent settlement by foreign workers. The state had also encouraged Javanese immigration, and most Javanese had become settlers and were recorded as Malaysians in census reports. Despite an earlier commitment to unrestricted immigration in the first three decades of the twentieth century, the British introduced legislation in the r 930 s that placed restrictions first on the entry of adult male Chinese and, in 1938, on all Chinese. This legislation was consistent with depressed economic conditions and the introduction of international commodity restriction schemes. The British were also able to turn off the immigration tap for Indians by repatriating a sizeable number to India using IIC funds. Thus the state, as both the regulatory agency and the labour broker (for Indians), was able to manipulate Indian migration flows to its advantage, facilitating migrant inflows during good times and repatriating/limiting their entry during bad times.

This period was also marked by a growing national consciousness based on race and ethnicity. From the standpoint of the Malays, and in the context of understanding contemporary immigration policy in Malaysia, Malay indigenism, which reared its head in the I930s, became even more strident in the I950s and I960s. By 1947 Chinese and Indians outnumbered the Malays (and Indonesians). Malaya's changing demographic structure is shown in Table $\mathrm{I}$.

Malaysia's present immigration policies may be traced to the Malayan state's chauvinistic and selective immigration policies instituted after it became independent in 1957. The Immigration Act of 1959 resulted in a tightening of admission rules under the reunification of families clause, and prohibited entry of spouses and children of Malaysian Chinese and Indian residents who had been living apart from their husbands for a continuous period of five years after December i954. Subsequently, the 
state passed the 1968 Employment Restriction Act, which made admission to the labour market for non-citizens conditional on their possessing work permits or labour contracts. The work permit system was also intended to ensure that only skilled non-citizens would be allowed admission into the country. Foreigners or "aliens" who had not taken out citizenship had to leave or were repatriated. A new era thus unfolded in Malaysia for international labour migration.

\section{THE ROLE OF THE STATE AND LABOUR BROKERS IN MALAYSIA SINCE THE 1970S: CONTINUITY AND CHANGE}

The colonial history of Peninsular Malaysia sets the stage for some nuanced discussion of present migration policies, of what has changed, and what has remained the same, to better understand migration regimes and the role of labour brokers in the country.

As noted earlier, after independence in 1957 the Malayan/Malaysian state introduced immigration controls to stop Chinese and Indian immigrants entering the country. The 1968 Employment Restriction Act was intended to restrict the quantity and manipulate the "quality" of migrants and ensure that only skilled non-citizens were permitted entry into the country. Thus, the new Malaysian nation state became a closed labour market, and citizenship conferred both the right to reside and work in the country. Concurrently, a large number of Chinese and some Indians migrated to Singapore after it was expelled from the Malaysian federation in 1965. Although low-skilled immigration was restricted, low-skilled Indonesian workers spontaneously migrated to Malaya since they were not classified as aliens. The Indonesians utilized informal entry channels, building on their pre-World-War-II networks, and Malaysian firms recruited a large number locally, particularly for the plantation, construction, and domestic work sectors. Occupational mobility was high among these migrants, especially in the construction and agricultural sectors, and labour brokers continued to play an important role in the transportation and job placement of new migrants.

After 1987 Malaysia was transformed from a net labour exporter to a labour importer. This transition was also very rapid and occurred long before Malaysia achieved full employment and when its GNP per capita was only about US\$ I, 800. ${ }^{30}$ Malaya's dependence on labour migration also occurred against the backdrop of a pro-natalist population policy and domestic labour force growth of 2 to 3 per cent.

Next, following race riots on I 3 May 1969 Malaysia adopted an interventionist regulatory policy known as the New Economic Policy, which inaugurated an affirmative action strategy for the Malays (and other 
indigenous communities). The state also became the pre-eminent player in economic development, implementing poverty reduction and income redistribution schemes for the Malays. Apart from the industrialization programme, large-scale development projects including infrastructure and land development schemes were commenced under the management of government agencies. The construction and plantation sectors also expanded, and this growth took place against the backdrop of a tight labour market, consistent with sustained fertility decline and restrictive immigration policies. According to a World Bank Report, ${ }^{3 \mathrm{I}}$ I4 million new jobs were created during the period 1987-1993, while the labour market growth rate was 3.9 per cent per annum. The domestic labour force growth rate during this period was 3.I per cent per annum. Thus the only realistic alternative for the Malaysian government was to implement a temporary worker policy for labour force growth.

The analogies between the colonial and independent Malaysian migration policies are remarkable. The main features of the new policy are: a guestworker rotation system; employment through intermediaries and offshore recruitment procedures; the provision of assisted passage for workers; repayment of advances through salary deductions; employment with a specified employer; fixed-term employment; and the obligatory return to the country of origin upon completion of the contract. The guest-worker programmes guarantee labour market flexibility and include restrictive admission policies to limit the size of migrant labour flows. The state, labour brokers, and migration agents consequently play a far more important role in the present period compared with the earlier period, due to increased risks in migration processes. The major risks faced by prospective migrants, particularly low-skilled migrants, include a lack of detailed information on where jobs are available, Malaysia’s legal system, employment laws, working conditions, and where they can seek redress from unscrupulous employers who falsify information or refuse to pay them.

Unlike the colonial period, gender is an integral part of contemporary labour mobility, and most low-skilled migrant women work in gender-specific jobs, principally as domestic workers and caregivers. They are employed in the private home and are beyond the radar of official state oversight and associated legal protection. Essentially, the entry of more women into the waged economy in higher-income south-east Asian countries, coupled with the commodification of domestic service work (housework, childcare and elderly care), has resulted in the transfer of these tasks to less-well-off women from poorer countries in the region. This arrangement absolves the state from providing state-funded childcare and elderly care services. The rise in

31. World Bank, Malaysia - Meeting Labor Needs, More Workers and Better Skills (Washington DC, 1995), p. 58. 
dual-career families and the construction of middle-class identity and status has also led to a pattern of assigning responsibility for hiring/supervising domestic service workers from the state to prospective employers.

\section{The Malaysian state, labour migration policy, and state regulation}

Against the backdrop of continuing spontaneous migration by Indonesians, the state instigated institutional and policy changes which led to new programmes for managing labour migration, engaging constructively with migrant-sending countries, and achieving good outcomes for Malaysia. Importantly, the state's immigration reforms and the need for controls prompted the realignment of the Malaysian immigration system, from an earlier "liberal" recruitment policy for Indonesian labour to evolving border controls to prevent unauthorized migration and the official regulation of migration. The revised policy included a law enforcement strategy and securing borders alongside regulating and managing an expanded foreign labour programme and addressing workforce needs. Crucially, it involved participation by the private sector.

Malaysia's immigration policies and programmes, foreign labour recruitment methods, and labour migration are best observed through four fairly distinct phases since the I970s. During the first phase, 1970-1979, the Malaysian government did not have a comprehensive policy to address labour shortages, nor did it utilize one for foreign labour recruitment. Malaysia espoused a "liberal" approach, which saw minimal intervention in the recruitment of low-skilled foreign labour by employers. Much of this foreign labour comprised undocumented Indonesian workers who lived in the Indonesian squatter settlements in Kuala Lumpur. ${ }^{32}$

Three broad trends relating to changes in labour supply and mobility soon became evident in the country. First, there was increased internal migration from rural to urban districts by both men and women. Malaysian women's economic participation in the manufacturing sector, particularly in manufacturing industries in export-processing zones, also expanded rapidly. Second, the rural-urban migration resulted in labour shortages in the agricultural and construction sectors, at a time when the state had launched massive land development schemes in both Peninsular Malaysia and East Malaysia. Third, as demand for low-skilled labour expanded, the existing social networks and pre-existing channels for long-standing informal Indonesian immigration flows were reinvigorated and led to new influxes of irregular migrants.

During the second phase, 1980-1990, the state addressed the issue of labour force growth and its need for a guest worker policy in two main ways. First, in 198 I Malaysia introduced a Private Employment Agencies tions", Indonesia and the Malay World, 7I (1997), pp. 50-82. 
Act allowing private labour brokers and agencies to recruit foreign labour for Malaysian employers. The agencies had to be licensed and their recruitment fees had to comply with government schedules. The foreign workers had to be provided with work permits and their employment had to be regulated under the 1968 Employment Restriction Act and the 1957 Immigration Act. This recruitment policy tied workers to particular employers and localities. The government also formed a Committee for the Recruitment of Foreign Workers in 1982 that was tasked with the allocation of work permits to guest workers.

Next, the government signed labour accords with labour-sending countries to streamline recruitment procedures and establish legal recruitment channels. In 1984, for example, Malaysia signed the Medan Agreement with Indonesia to recruit Indonesian workers for the agri-plantation and domestic work sectors. In 1985 Malaysia signed a labour accord with the Philippines for the recruitment of domestic workers. Subsequently, employers were permitted to recruit workers from Bangladesh and Thailand for the plantation and construction sectors, and the employment of Indonesians in the plantation sector was also formalized. The labour accords also established formal recruitment channels between source countries and Malaysia. Crucially, the state authorized employers and private recruitment agencies to handle recruitment, and an offshore recruitment policy was developed with the state's role confined largely to immigration formalities and regulations. Despite these measures, unauthorized immigration continued to increase, especially from Indonesia, despite worsening economic conditions in Malaysia. The need to impose some control over labour moves also led to a regularization programme for undocumented Indonesians in the plantation sector in 1989 , followed by the suspension of Indonesian labour recruitment in January 1990.

During the third phase, I99I-I996, Malaysia's growing labour needs were further evaluated in the context of strengthened border controls. Thus border controls were largely understood in the framework of the movement of migrant workers. New policy measures were also formulated for the importation of foreign labour. The state's immigration policy centred on the recruitment of highly educated and skilled migrants, together with the recruitment of low-skilled workers for the labourintensive sectors. In I99 I a Cabinet Committee on Foreign Workers was formed to coordinate and regulate foreign labour recruitment procedures and monitor foreign worker arrivals. The heightened security focus was tied to better data collection and the state also introduced an annual levy (or tax) on migrant workers. This tax on migrant workers varied by sector and skill category (general, semi-skilled, and unskilled) and was payable by either the employer or the foreign employee.

Figure 5 provides information on the criteria used by the state in the selection of migrant workers in certain sectors. 


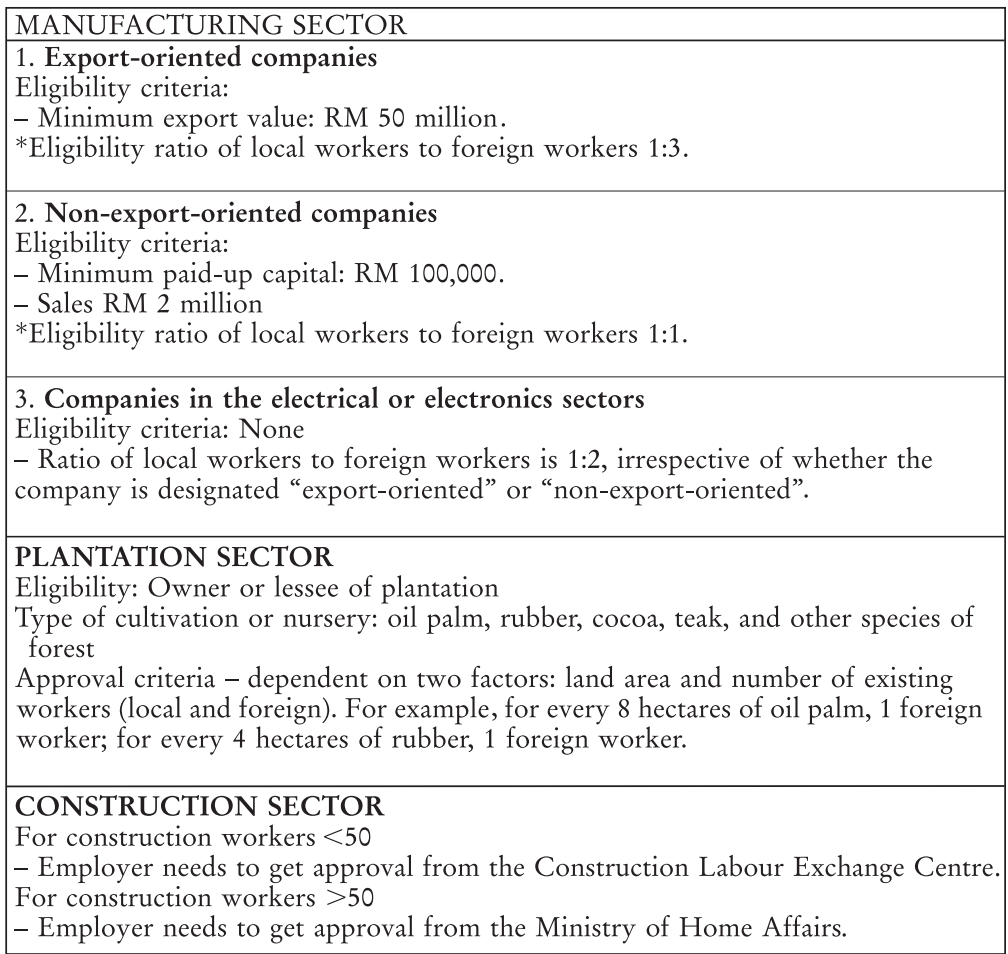

Note: A foreign worker is initially allowed to work for three years only and the worker's application may be extended on an annual basis until the fifth year. Further extensions are allowed only upon application to the relevant certifying authorities after the fifth year, and on the worker's status being upgraded to that of a skilled worker. This classification also promotes circular migration.

Figure 5. Malaysia: criteria for employment of foreign workers in selected sectors. Adapted from Haji Shamsuddin Bardan, "Terms and Conditions of Employment (Foreign Workers)/Unionism" (typescript, 2006).

From November I991 to June 1992 the government also commenced a regularization programme (referred as Ops Nyah [Expunge] i and Ops Nyab [Expunge] 2) to stop "illegal infiltration", weed out "illegal immigrants", and regularize undocumented foreign workers in Peninsular Malaysia. The regularization programme inadvertently led to labour shortages in the manufacturing sector, which were considered too risky for the country's industrialization strategy. Thus, in I995 the government established a Special Task Force on Foreign Labour as the sole agency responsible for recruiting foreign labour (excepting domestic workers and shop assistants). This task force was set up as a "one-stop agency" to deal with the recruitment and processing of migrant labour. This measure explicitly established the role of the state as the sole institution authorized to 
organize the importation of foreign labour. It was also intended to reduce exploitation of migrant workers by private recruitment agents. Kanapathy considers this move as both an "explicit" policy on labour importation and "an interim solution to meet excess demand for low-skilled labour". ${ }^{33}$

The state also expanded the Immigration Department's role to include implementation of Malaysia's foreign labour policy; to identify "suitable" labour-source countries; and to determine the eligibility of sectors applying for foreign workers. The department was also assigned to advise on the duration of labour contracts and on levies imposed on foreign workers. Briefly, a foreign labour recruitment policy, based solely on an offshore recruitment system, was implemented by the state to replace the "on-site" recruitment of undocumented and irregular labour. Licensed employment agencies were no longer permitted to recruit foreign workers, with the exception of domestic workers. Domestic workers were seen as a special case, since they were not covered by Malaysia's employment regulations.

The Asian financial and economic crisis of 1997-1998 marked the start of the fourth major phase in Malaysia's evolving immigration policy. The crisis triggered a steep recession in the country in 1998, resulting in a greatly revitalized focus on security issues and overdue reforms for labour recruitment. Data collection on migrant workers to determine their legal status was also increased. In view of the large numbers of irregular migrants, the government established detention centres to detain them "judicially", followed by administrative detention of undocumented workers in detention depots. The state also relied on amnesties and regularization programmes to encourage undocumented workers to register with the authorities and to have their status in Malaysia legalized.

In March 1997 the Task Force on Foreign Labour was disbanded and foreign labour recruitment was placed under the Foreign Workers Division of the Immigration Department. The Malaysian government also amended the Immigration Act in 1997 and again in 2002 to remove ambiguities and tighten regulations; it also further increased the penalties on both employers and workers in breach of immigration regulations. It thus became a criminal offence for foreign workers to work without a work permit or visa, and the state introduced punitive measures, including judicial caning of workers. ${ }^{34}$

33. Vijayakumari Kanapathy, "Migrant Workers in Malaysia: An Overview", country paper prepared for the Workshop on an East Asian Cooperation Framework for Migrant Labour, Kuala Lumpur, 6-7 December 2006, available at http://www.isis.org.my/attachments/ 38I_VK_MIGRATION-NEAT_6Deco6.pdf; last accessed I 2 May 20 I 2.

34. Amarjit Kaur, "Order (and Disorder) at the Borders: International Labour Migration and Border Controls in Southeast Asia", in idem and I. Metcalfe (eds), Mobility, Labour Migration and Border Controls in Asia (Basingstoke, 2006), pp. 23-51. 
The government also continued with its periodic expulsion of irregular migrants within specified timeframes.

The state recruited the services of a non-state actor, the Ikatan Relawan Rakyat Malaysia (RELA), or Peoples' Voluntary Corps, in its campaign or "war" against irregular migrants (including refugees and asylum seekers). RELA had been formed in 1972 to assist, maintain, and safeguard peace and security in the country and to undertake community projects. Volunteers were given training and were "expected to act against virtually all types of anti-government activity", and promote government objectives. ${ }^{35}$ The state subsequently allowed RELA personnel to be armed, and their new duties included instructions to "stop, search and demand documents, arrest without a warrant, and enter houses or premises believed to house irregular migrants" ${ }^{36}$ Consequently, the state has transformed RELA into a valuable ally in Malaysia's war against irregular migrants. RELA personnel also humiliate and carry out judicial caning of undocumented migrants, and "destroy the ID [identification cards] of legal migrants to justify the raids". They are also "immune from prosecution in relation to their conduct". ${ }^{37}$

The state has further created a climate of fear, and forces unauthorized migrants to depart "voluntarily" during trade downturns. Thus, instead of utilizing the services of public law enforcement officials the government continues to criminalize migrant workers, deny them natural justice, and compel them to rely on intermediaries and precarious boats to escape. The saga continues. It is clear that the Malaysian state relies heavily on migrant workers, but vacillates between indecision and repression since it is sensitive to electoral cycles.

Crucially, since Malaysia's share of foreign investment has been dropping, the state has promoted the formation of labour-hire or outsourcing companies to encourage investment in small and medium enterprises (SMEs) that require fewer than fifty workers. The rise of these SMEs correlates with the push by multinationals such as Nike to outsource production to supply chains or "boutique" contract factories in Malaysia for the manufacture of clothes and sports shoes that carry their brand names. According to media and other reports, ${ }^{38}$ a Malaysian firm (Hytex)

35. John Funston, Malay Politics in Malaysia: A Study of the United Malay National Organization and Party Islam (Kuala Lumpur, 1980).

36. Suaram (Suara Rakyat Malaysia), Malaysia Human Rights Report 2005: Civil and Political Rights (Petaling Jaya, 2006), pp. I 20-1 2 I.

37. FIDH-Suaram, "Undocumented Migrants and Refugees in Malaysia: Raids, Detention and Discrimination" (2007), p. I 2, available at http://www.fidh.org/IMG/pdf/MalaisieCONJ489 eng.pdf; last accessed I 2 May 20 I 2.

38. BSR International, "International Labor Migration: A Responsible Role for Business" (October 2008), p. 6, available at www.bsr.org/reports/BSR_LaborMigrationRoleforBusiness.pdf (last accessed I 2 May 20I2); Oxfam Australia, "Forced Labour by Nike Supplier", https://www.oxfam. org.au/2008/07/forced-labour-by-nike-supplier (last accessed I 2 May 20I2). 
used labour brokers in Burma, Bangladesh, and Vietnam to recruit migrant workers for a Nike supply factory in Malaysia. These workers subsequently paid about a year's wages to the labour hire company for the privilege of employment and were rewarded with extremely poor housing, confiscation of passports, and forced labour conditions, since they could not leave without documentation. Simultaneously, "niche" agricultural farms employing fewer than fifty workers also mushroomed. The incentive to hire workers under this recruitment method had arisen because employers in the manufacturing (and agricultural sectors) found it difficult to obtain local workers in the country's segmented labour market. These enterprises allegedly have less attractive labour conditions and fewer enterprise accountability concerns. ${ }^{39}$

Effectively, the outsourcing system has transformed the migrant workers into bonded labour, ${ }^{40}$ and horror stories of their exploitation have been reported in the media. A large number of workers, who sold off their family plot or borrowed heavily to "pay" for the privilege of employment in Malaysia, were left stranded at the airport in 2008, or were paid a fraction of what they had been promised. ${ }^{4 \mathrm{I}}$ The Malaysian Trades Union Congress has reported that the activities of these labour-hire firms "has worsened the problem of human trafficking" in Malaysia since they "bring in as many as 500 workers each", who are then "sold or outsourced". ${ }^{42}$ According to Human Rights Defenders, the outsourcing agencies also weaken protections since they have become the "employers" and most hold workers' passports, pay on an irregular basis, and charge workers for sub-standard housing and food.

In the past four decades, there has been a marked shift in Malaysia's foreign labour recruitment policy. From a "weak", or rather ad hoc, start in the I970s, when Indonesian workers were freely allowed to move to Malaysia, the state subsequently permitted private labour brokers to carry out recruitment and placement tasks. Subsequently, hundreds of small recruitment agencies flourished, functioning as labour brokers in a highly competitive environment. This policy measure resulted in a rise in irregular migration, and the more visible presence of migrant workers in the cities as well. Consequently, these workers have been blamed for rising levels of crime in the country.

39. Tenaganita, "Fact Finding Report: Outsourcing in Labor or Trafficking in Migrant Labor?" (typescript, 2007).

40. Irene Fernandez, "Recruitment and Placement of Migrant Workers in Malaysia", paper presented at the Malaysian Bar Council Conference on Developing a Comprehensive Policy Framework for Migrant Labour, I 8-19 February 2008, Kuala Lumpur.

4I. "Worker Rights Violations at Nike Factory in Malaysia", Associated News, I August 2008. 42. Humantrafficking.org, "Malaysia Reconceptualizes its Assumptions about Human Trafficking”, I7 May 2007, available at http://www.humantrafficking.org/updates/622; last accessed I 2 May 2012. 
In 1995 the Malaysian state legislated to manage directly the movement of foreign workers by taking over all regulatory functions, and it became the sole regulatory agency in the state for almost all categories of less-skilled migrant worker. Apart from the outsourcing firms, private labour brokers are also allowed to recruit domestic workers, and have formed an umbrella organization known as PAPA. Since women have less educational and social capital, they are recruited through "sister" agencies in source countries. They do not have to pay any money to travel abroad, but they are required to attend training in the use of appliances and some language instruction. All their travel costs are paid. However, Malaysian employers are charged for this and the domestic workers are not paid for three months, so that the agency and employers can recover their recruitment costs. This highlights the gendered dimensions of women's migration in south-east Asia.

Crucially, Malaysia's foreign labour policy, labour brokerage practices, and the high levies imposed on guest workers have also contributed to the expansion of irregular migration. The government has introduced some reforms to regulate foreign labour inflows and crafted policy tools based on labour accords to attract low-skilled migrant workers. Like other countries, Malaysia also utilizes the regularization of irregular migrants as a policy instrument to extend legal status to undocumented migrants. These policy changes underpin the state's increased drive for labour flexibility and reduced employment entitlements to migrant labour. 